\title{
A CONVERSATION WITH CONDOLEEZZA RICE
}

\section{On Leadership}

\author{
Henry Louis Gates, Jr. \\ The Alphonse Fletcher University Professor, Harvard University \\ Condoleezza Rice \\ Former U.S. Secretary of State, Thomas and Barbara Stephenson Senior \\ Fellow on Public Policy, The Hoover Institution, Stanford University
}

Condoleezza Rice, Extraordinary, Ordinary People: A Memoir of Family. New York: Random House, 2010, 352 pages, ISBN 978-0-307-58787-9. Hardcover, $\$ 27.00$.

Henry Lous Gates, JR.: Secretary of State Condoleezza Rice, thank you very much for granting me this interview.

CondoleEzza Rice: It's a pleasure to be with you.

Gates: How do you define a leader?

RICE: A leader is someone who inspires others toward a common goal. The most important thing about leadership is to remember that you are trying to bring people together to achieve something. And none of us wants to be pushed and shoved in any particular direction, so if you treat the people that you're leading with the same respect with which you would like to be treated, then I think you are a good leader.

GATES: Are leaders chosen or are leaders made?

RICE: I think leaders are made. I have never believed that anyone is born to anything. And leadership is also something that I think you get better at over time. In many experiences, as a younger person trying to lead a university or leading people, you make mistakes because you're young and maybe a little too aggressive. I think leaders are not only made, but they get better at leading over time.

GaTES: Let's talk about that idea with regard to your own upbringing. When I looked at your family pictures, I particularly noticed the way your parents looked at you. They seemed to be looking at someone who was going to be a major player, going to be a leader. Is that a self-fulfilling prophecy, do you think, the kind of reinforcement through self-esteem that is part of the air that you breathe?

Rice: There is no doubt that without John and Angelina Rice, I would not have ended up where I did. I grew up in the segregated South where the messages could have been absolutely crushing, but somehow my parents made the messages about

Du Bois Review (2011) 1-16.

(c) 2011 W. E. B. Du Bois Institute for African and African American Research 1742-058X/11 \$15.00 doi:10.1017/S1742058X11000105 
empowerment, which is no small trick in and of itself. They also, from a very young age, wanted me to understand that I should want to make decisions. So I was president of the family from age four. I remembered this as I was writing my book and I thought, 'What in the world were they thinking?' I think they were just trying to give me a sense that even in the family context, it was all right for this four-yearold to have real responsibilities and to carry them out.

GATES: Your parents are just extraordinary. Did you find that your friends had a similar relationship of intimacy and equality, given the limits, with their parents? Was it a class thing or was it unique to your parents?

RICE: I suppose it was, in part, a class thing. I think in middle class Birmingham, in the little enclave in which we lived, Titusville, most of the families, fortunately, were two-parent families in which both men and women worked. So girls received early signals that they could have a profession, could have a career. Most of my friends, just like my parents, gave me every opportunity and, in fact, some opportunities you didn't even want-to play in recitals and to stand up and give little speeches. That was all part of the ether in Birmingham. But of course, I was an only child. I've always said it is easier to be an only child than to be a parent of an only child [laughter]; when the friends go away and the little one needs somebody to play with, the parent has to stand in. So probably the real difference is that I lived in a more adult world than my friends did. They had siblings. They could go home and play with those siblings. My parents had to be my playmates after dark.

GATES: So this little girl, who was reared on the idea that strength and discipline and leadership were expected of you, grew up to be Provost of Stanford University and U.S. Secretary of State! More than anyone else I know, you have had an opportunity to observe leaders in action. What makes a good leader? Can you give an example of someone who has been a model for you of leadership?

RICE: A good leader has to have a vision of where they are leading people. If you don't know where you're going, then you're not going to be able to bring others around a common goal and a common vision. But that vision has to be, on the one hand, realistic. It can't be pie-in-the-sky or people won't warm to it. They will ridicule it. On the other hand, if the vision is too confined to the world as it is and doesn't have a strong sense of the world as it should be, then it's not inspiring. So I have always found that the best leaders are people who have that vision that pushes people to think about what is possible, but shows them a realistic way to get there. And I have been fortunate to see a lot of great leaders.

One of the strongest leaders I ever encountered was the woman who is currently the president of Liberia, Ellen Johnson Sirleaf. When you talk to her about Liberia, and you are standing in Liberia, you say to yourself 'what is she seeing?' I remember when we first went to Liberia after she had been inaugurated as president. I was there for her inauguration. It was an extraordinary event. But we were going up to her office, which I think was on the fifth floor, and the elevator simply quit. It just stopped because electricity was so rare in Liberia. And she, very proudly, said, 'Oh, don't worry. The next time you come, that'll be fixed.' So this is somebody who, in these very dire circumstances, has painted a vision for the future that I think Liberians are warming to and are inspired by. We sometimes decry vision and we talk about people as being too idealistic, but if you are not an idealist, if you're not an optimist, then you can't lead.

GATES: So one needs to be an idealist sufficient to paint the dream and a pragmatist sufficient to create the pathway to the dream.

RICE: That's right. And very often you will find people who are good at one or the other, but not at both. The best leaders are people who are good at both. 
GATES: How long were you trapped in that elevator?

RICE: Well, fortunately, we were able to kind of pry it open [laugbter]. Then we had to walk five flights of stairs in the Liberian heat. That wasn't much fun either. Because the air conditioning was also long gone.

Gates: If leaders can be made, which you said they can, what are some of the important lessons, from your experience, that you would offer to an aspiring leader, particularly in the Black community?

RICE: Well, I very often encounter young people and they say, 'I want to be a leader.' In my opinion, that is the wrong place to start. The first questions to ask are 'What am I passionate about? What do I care about? What am I going to learn enough about to actually have something to say about it?' And then an aspiring leader should ask him or herself, 'How am I going to acquire that knowledge and that expertise so that I'm not just talking through my hat?' as we might have said where I grew up in Alabama. And once you have started on that path, you can have early leadership experiences by taking on hard jobs. If there is something somebody doesn't want to do, you do it. And do it with a lot of vigor and a lot of enthusiasm. And that is a great leadership experience.

GaTES: It's like Booker T. Washington, sweeping the room. . .

RicE: Absolutely. Because I am a professor, I often reflect on how to talk about these issues with young people. I have had students say, 'I don't want an internship where I'm just going to be stuffing envelopes.' And I say 'Well, perhaps when you start that internship, all you are capable of doing is stuffing envelopes. But as you demonstrate that you're more and more capable, you will get greater and greater responsibility.' Those who emerge as leaders are people who have demonstrated that they can take responsibility in the hardest circumstances, mobilize others, and move them forward.

GATES: Let's talk about young people a bit more. I know how deeply troubled you are, as am I, about the fact that seventy percent of Black children are born to a single mother. When you were talking earlier about the nuclear family in your neighborhood, not only did your friends have two parents who lived together, but they both worked. So did I, in West Virginia. How do we translate these lessons for future generations? Particularly, those lessons about entrepreneurial leadership for the large part of the Black community that was not privileged to be raised in the environments in which you and I were raised?

RICE: Well, unfortunately, the nuclear family is still in decline. The data get worse, not better. And we cannot simply sacrifice the kids who find themselves in that condition by saying we really should be trying to build nuclear families. We should be. But for children who are not fortunate enough to have that, some adult-a minister or a teacher-needs to step in and advocate for that child. No ten-, fourteenor eighteen-year-old is going to be able to navigate the complexities of life in America alone, particularly life in America for a minority kid. In many communities, even when I was growing up, it was a teacher who would step into the role of advocate or mentor. While my community was middle class and we had two-parent families, not every community in Birmingham was middle class. My parents and their friends, as teachers, very often took on responsibilities for helping isolated kids to navigate the world. I tell a story in Extraordinary, Ordinary People about my father, a Presbyterian minister, and the youth fellowship at his Black middle-class church. Behind that church was a government project called Loveman Village, where twoparent families were less common and parents were often not educated people. Kids from all over the community came to youth fellowship. I later teased my father that the reason his youth fellowship was so popular was because he was a Presbyterian 
minister and so he could host dances. The Baptists couldn't [laughter]. But in that youth fellowship, my father and the church sent messages: 'Your kid is smart. Your child ought to go to college. I've got a scholarship for your child from Spelman College or Knoxville College. And I want your kid to go to college. Your daughter or your son.' So, it is not ideal if there has to be a substitute for the nuclear family, but in our world, we may have to rely on others to advocate for those children.

GATES: It takes a village.

RICE: It does take a village.

Gates: You have learned a great deal from these different communities you've inhabited: segregated Alabama, the academy, the White House. You must have observed many different leadership styles. Did you deliberately set out to emulate or adopt a particular style of leadership?

RICE: I believe that you learn a lot about leadership as you take on leadership positions. I remember my first year as provost at Stanford. I was pretty tough. I was a thirty-eight-year-old provost. Though I had had tenure for a number of years, I had never been a department chair. Nevertheless, I was promoted to full professor in May, and to provost in June. And so-

GATES: That's amazing.

RICE: Well, the president of Stanford, Gerhard Casper, took this chance. But in those first few months, I really felt I had to assert my authority. And I did it sometimes by not delegating and not letting people do their jobs. And if something wasn't accomplished in three or four days, then there I was trying to do it for them. I had a long talk with my father in the summer after my first year as provost, and he said 'Let me tell you something. If somebody is trying to do their job, but they're not doing very well, your job as a leader is not to go do their job, but to help them figure out why they're not getting it done. Because if you don't do that, pretty soon nobody who is any good is going to work for you because they're going to be tired of you constantly taking over.' I learned a very important lesson from that. When I then became national security advisor and, particularly, secretary of state, where I had a 55,000-person department to run. . .

GATES: It's hard to micromanage that.

RICE: But I had learned that when something isn't getting done, perhaps you can intervene to help that person. That's a very different concept. It's more collaborative and more about working with people to help them remove barriers. So those are the kinds of lessons that I think you learn by having leadership experiences and maybe not doing it as well as you might the first time around.

GATES: You benefited, obviously, from great mentors, starting with your parents. I'm asked to speak in corporations all the time, particularly by minority people, about the secret to success. And I say, from my point of view, it's about finding a great mentor, being adopted by a mentor. But then they say 'Well, how do you do that?' What is your advice for finding a mentor?

RICE: Well, first to recognize that you need one. And that is the first step because the idea that anybody gets there on their own is one of the great fictions in society. Everybody needs somebody to help them navigate their course and advocate for them, to push them ahead. Secondly, you have to be pretty aggressive about finding mentors. And I know that it is ideal if you can find mentors who look like you. But it really may not be possible. Some of my most important mentors-as a matter of fact, all of my early mentors other than my parents and a few teachers-were White men. In fact, they were old White men, because they were the people who dominated the fields in which I was working: International politics, Soviet Studies. I would have been waiting a long time to find a Black female mentor in Soviet Studies. So being 
comfortable with the fact that they may not look like you is important. And third, trying to seek out people in whom you are interested. I very often say to my students, you know, we're a little bit vain as faculty. If you think this is somebody you're really interested in getting to know, go read something they've written. Then go talk to them about it. And try to establish a relationship. You can't be shy about seeking out mentors. Many people love to be sought out in that way and want to help, but you need to have something in mind that you would like to have them help you do; for instance, get a fellowship or an internship. Ask them 'Can I help you with that project?' I think we have made mentoring too formal a term. What we really mean is finding people who will help you out, who will think about you when a possibility comes along, and who can give you a little advice along the way.

Gates: One crucial mentor for you was Josef Korbel, Madeleine Albright's father. Could you tell us the story of how this relationship came into being?

RICE: It came about because I was a failed piano major [laughter]. I started playing piano when I was three years old. I went off to college to be a piano performance major, and at the end of my sophomore year in college, I went to the Aspen Music Festival School. And I met twelve-year-olds at the Aspen Music Festival School who could play from sight what it took me all year to learn. I was seventeen. I thought 'I'm about to end up teaching thirteen-year-olds to murder Beethoven for a living and that's not what I want to do.' So I went back and said to my parents 'I'm changing my major.' They said, 'What are you changing it to?' I said, 'I have no idea.' They said, 'You don't know what you want to do with your life?' I said, 'Right, it's my life.' They said, 'It's our money, find a major' [laughter]. And so, after a couple of false starts, one in English literature, which I didn't like, and one in local government, which I liked even less, I literally wandered into a course in international politics just thinking 'Oh, it fits into the right time slot on my schedule.' And it was taught by Joseph Korbel. All of a sudden, I knew what I wanted to do. He opened up this world of international affairs and diplomacy and the Soviet Union and Russia, and it was like finding love. All of a sudden, inexplicably, for a Black girl from Birmingham, Alabama, I wanted to be a Soviet specialist. And he continued to nurture that interest. I remember giving a presentation in his class and he said, 'You should be a professor.' I remember thinking, 'Oh, come on, me a professor?' So he was a very good mentor because he kept helping me to define what I wanted to be. He didn't try to impose a view on me. He was a terrific mentor.

Gates: Were your parents supportive or did they say have you bumped your head out there in Denver? A Black Russian ...

RicE: Exactly [laughter]. No, fortunately my parents didn't say 'Why in the world is a Black girl from Birmingham talking about being a Soviet specialist?' They said, 'That's great, honey, go for it.' And they were thrilled. I'm not sure they knew what a Soviet specialist did. But they were happy to support it.

GATES: You were lucky.

RicE: I was lucky. I used to say, when I would address parents at Stanford as provost, 'When your kid comes home and says 'mom and dad, I've found it. It's Etruscan art.' Don't panic. It might in fact turn out all right' [laughter].

Gates: In those early days of your education and career, was there a moment when you realized that you were going to be a leader?

RICE: Oh, I still don't think of it in those terms. I think that I have had special experiences and unique circumstances. I don't think I am a particularly unique person in that regard.

Gates: You are the first Black female secretary of state.

RiCE: I know, but I . . . 
GATES: In history.

RICE: But it's a combination of preparation and circumstances. I was fortunate to find something I loved doing. International politics. Soviet specialist. I happened to be fortunate that a Soviet specialty was hot property in 1981, 1982, when I came out of college. I am fortunate that I meant Brent Scowcroft, who would become George H. W. Bush's national security advisor. I had done my work and I had worked hard. I had learned Russian. I had done the basic research. And I had written articles that identified me as a rising young Soviet specialist. Scowcroft took me to the White House as the special assistant to President Bush for Soviet affairs, and I was fortunate to be in the right place at the right time. I got to be the Soviet specialist at the end of the Cold War, because in 1989, everything broke loose in Europe. Now, some people say serendipity. But I say, some combination of serendipity, good luck, and maybe divine intervention [laughter], but that's how I see what emerged for me.

GATES: Fair enough. Does being a leader necessarily mean that you'll be isolated from those you lead?

RICE: You have to have just a little distance from those that you lead. I don't think that a leader can just be one of the gang. Sometimes you have to make really hard calls that you would not want to make with your friends. Sometimes leaders can bring everybody together around an idea and there's consensus and we can all be very happy, but sometimes a leader has to say 'All right, we've had enough discussion, this is what we're going to do.' And a little distance helps you when you have to do the second.

GATES: I feel the same way about not allowing my students to call me by my first name, which is very unpopular now. Many of my colleagues will insist, but you create this false sense of equality, of intimacy, and then you could clunk them. I think it's unfair. It confuses people.

RICE: I think it is confusing. My students call me Professor. My graduate students call me Professor, and the day that they graduate, they call me Condi.

GATES: But can a leader be loved and respected?

RICE: I think a leader can be respected. I don't know if loved is the right term. You can be admired. And I hope that as a leader, I have been admired. I do think you can be admired as someone who cares a lot about the people who work for them. And maybe that is the closest thing to being loved. You ought to care about what is happening to people, for example, if somebody's family situation is difficult. You ought to care if somebody is having difficult health issues. You ought to care if somebody is not feeling fulfilled in what they're doing. Caring about the people who work with you and for you is a very important part of leadership. And when you think about it, you would like to be cared about. You don't want people to just be cold and uncaring about what's going on in your life.

GATES: It must be very, very painful being in the White House watching the polls and seeing the President or the administration taking flack. How do you bolster a leader, at the worst time, whose feelings are hurt?

RICE: Well, it helps to have a sense of humor. And all of the leaders with whom I have worked-the two presidents with whom I've worked and even the president of Stanford-had great senses of humor about the views of the outside world about them. I was fortunate to work with people who have a firm grounding, a kind of center to themselves, so that they are not thrown off course by every headline; it makes it a lot easier to get through tough times. It is also particularly important to remember, in national and international leadership, that history has a long arc, not a short one. What people think about you today may not be what they think about you tomorrow or, most importantly, what history will think about you. I often think 
about Harry Truman who was perhaps, in my opinion (and I know many people will be surprised), the greatest president of the twentieth century in the United States.

GaTes: Greater than Franklin Roosevelt?

RicE: Even so. Franklin Roosevelt was great for what he took the country through, of course. But from my perspective as somebody who cares about America's role in the world, it was Harry Truman that figured it out. And he did it by taking really tough decisions. When he recognized Israel in 1948, George Marshall, who was his secretary of state, told him (maybe it's apocryphal, but I think its probably true), 'I will continue to be your secretary of state, but I'll never vote for you again.'

GATES: Really?

RICE: Marshall was furious. He thought that it was going to throw the world into turmoil, and in fact, war broke out in the Middle East the next day. Harry Truman's decision in 1948 to recognize Israel turns out to have been one of the most important decisions of the twentieth century. But he took it because he felt it was right. He was the one, of course, who believed the integration of the armed forces could take place and it was not going to diminish morale as everybody said it was going to do. This was a man who really took tough decisions and when he said 'The buck stops here,' he meant it. When you aren't so focused on today's headlines, you are a better leader.

Gates: And the chaos following Truman's decision on Israel ended up securing the Nobel Prize for Ralph Bunche.

RICE: That's right.

GATES: Ralph Bunche brings me back to an earlier generation of Black leaders. Are we doing all we can to groom leaders within the African American community for the next generation?

RICE: Well, I do think we are seeing the emergence of African American leaders in a broad range of contexts. Clearly, we have a lot of African Americans now in corporate leadership-leading corporations that we would never have dreamed of when you and I were growing up. That there would be a Black man heading American Express; could you have imagined that? So in the corporate world, I think we're doing much, much better. What is concerning to me, and I have sat on corporate boards, is when I look at the next couple of levels, I don't see as many Blacks moving into that pool, where the next set of CEOs are going to come from.

We need to be very concerned about that and, by the way, it is true in academia as well, and in government. We should not only focus on 'Well, somebody got to the top.' But there are pools from which people are chosen to get to the top. We should look at whether we are filling those pools with young Black Americans, and giving them the experiences. The military is terrific at seeing a bright young captain and saying 'That person looks like he's got the potential to be a colonel,' or 'she has the potential to be a general, but needs to have these career experiences in order to do that.' The corporate world is somewhat better at it, too. We are terrible at it in the government. I was stunned when I was secretary of state, to walk into room after room after room. I could go a whole day as secretary of state and never see anybody who looked like me. In the foreign service, it's still not diverse enough. But also, people are not moved in a way that means they're going to become assistant secretary, which is the position of responsibility from which you're going to get the major ambassadors appointed and so on.

GATES: But you were talking earlier about your father's youth group, which is leadership training. You went to Black schools, in which they spotted you. You would be nurtured. Is that happening within the race today?

RICE: I don't see it. Sometimes we old folks sound, you know, the way old folks start to sound. 'Well, back in the day ...' And back in the day, of course, we had this 
peculiar characteristic of being segregated and had, in a certain sense, second class citizenship. On the other hand, our parents had the ability to control the messages that their kids received, the ability in a Black school to demand excellence (as my school always said, 'You have to be twice as good') and to have it and have no racial overtones. What I worry somewhat about is that in integrated environments, you can get a couple of responses that are not very good for Black kids. One is to assume that they are somehow less capable and therefore to start to engage in noblesse oblige: 'Let's give them a little bit of a break.' Deadly. Secondly, to empower victimhood. I think one of the worst things you can let anybody tell you is that you're a victim of something. Because the minute you are a victim of something, you have completely lost control. And in a more integrated environment, sometimes in trying to recognize the challenges that are associated with being Black in America, it eases over into victimhood and that is a problem.

GATES: And that lets us make excuses for bad behavior.

RICE: That's right.

GATES: Or lacks in performance. I agree with you, and I don't think that it's just us being romantic or sentimental about the past. They demanded performance.

RICE: They sure did. They were caring, and I can remember my mother staying after school to help her science students who weren't doing very well, so they didn't just leave you hanging out there if you didn't perform. But you were expected to perform.

GATES: So should we have segregated schools again?

RICE: Well, of course we aren't going to go and shouldn't go back to segregated schools. But somehow, I do think within these great White institutions or great integrated institutions, it puts a special responsibility on, for instance, Black faculty, to remind Black students that there are no easy ways here. And when I was at Stanford, I started a program called Partners in Academic Excellence. This started when I conducted my first Phi Beta Kappa ceremony as provost. In the three hundred or so Phi Beta Kappas, I think there were two Black kids. I thought, 'Something is really wrong with this picture.' And I started to wonder if maybe something was wrong with the messages about excellence and so forth. We started Partners in Academic Excellence, where we paired Black freshmen with Black graduate students and a Black faculty member once a week. The Black graduate students would read the papers of the Black freshman for their Humanities requirement and they would say 'That's not an A paper that you just wrote.' So something was going on there, and we started to think about where else might this be the case, perhaps for other minority students, for athletes. There were lower expectations of athletes than there should have been in a place like Stanford. Or women and math.

So I'm a big proponent of really challenging kids. And it's not just minority kids. It's about seeping into our academic environments, our educational environments more broadly, with a kind of self-esteem movement. I was helping my cousin's daughter a few years back when she was about ten years old. She was doing math homework and she had $5 \times 9=40$. And I said, 'That's wrong.' And she said, 'There are no wrong answers' [laughter]. And I said, 'Oh yes there are, and that's one of them!' So recommitting to excellence and high standards is important because, going back to our theme of leadership, leaders have to have the highest standards for themselves and for the people that they lead. And people appreciate it when you have high standards.

GATES: When you walked into a room with the most powerful leaders in the world, when the door opened, did they see a Black person coming through first or a woman coming through first? 
RICE: Well, in most places, they first saw the secretary of state of the United States [laughter]. I have often said I really do think role definition might be stronger for women than it is for minorities. I think we are starting to get past role definition for Blacks. I could see it. I'm not a humanist and I'm certainly not a student of popular culture, but I remember thinking a few years back as I was watching a commercial, that it was no longer limiting the Black role. Your insurance agent just might happen to be Black, or your doctor might just happen to be Black. And something was happening where we were starting to divorce role and race. Now it's not complete, but with Colin Powell, people started to consider him as the chairman of the Joint Chiefs of Staff who just happens to be Black.

Gates: They started to, yes, but initially it was a shock. I had people in Latin America tell me about the first time they saw Colin Powell representing the U.S. military on television. They were in a bar, and the whole place stopped.

RICE: But now we take it for granted. Black secretaries of state, oh, well.

Gates: Dime a dozen.

RICE: And then, finally, the Black president of the United States. Now I don't believe we're a race-blind society; when somebody walks in your room, you still see a Black person. But maybe you are less likely, increasingly, to think this way, which is where I think we want to be. For women, particularly in positions of authority and particularly in positions having to do with national security and the like, it is also, finally, starting to break down.

GATES: But why? You would think, I mean there are so many more White women, powerful women, why would it be the way that race boundaries would break down before gender?

RICE: I think we have weird notions about gender. I go to these conferences from time to time and somebody will quite nicely and quite well-meaningly say, 'Well, women lead differently. They're consensus builders.' I say, 'Yeah, like Maggie Thatcher, right?' [laughter].

GATES: Or Golda Meir.

RICE: The fact is, when you think about it, it's a pretty ridiculous notion. But there is this concept with gender that somehow, women have the feminine and therefore softer side when they lead, and men are just going to go out there. And you say any good leader, male or female, has to have a range of assets, capabilities, and styles. Some days, it's 'Let's all come together and reason about this and we'll come to a joint conclusion.' And some days, it's 'I've had enough of this, we're just going to do it.'

GATES: Did you ever feel condescended to, even for a second?

RICE: When I was younger, I sometimes felt awfully young in the room. And in some places in the world-Russia, for instance-it's a very patriarchal society. I can remember giving my first big lecture in Russia, in the Soviet Union. It was at the home of the American ambassador and he had invited all these Soviet leaders and generals. And I gave the address in Russian. At the end of it, there was a dinner and I was seated next to a Soviet general and he essentially said, 'Why is a nice girl like you so interested in bombs and bullets?' [laughter]. I said something about actually being rather fond of military power or something to back him off. But a story appeared the next day in the newspaper saying that I should have been thinking about my suitors, but instead I was thinking about bombs and bullets. But not in many, many years has that been a problem.

GaTES: Turning to your book, as a public person, former secretary of state, you could have written an enormous memoir focused mostly on diplomacy, foreign policy, interactions with the world. You could have dropped names, made a million 
dollars, sold a zillion copies. So why make your first book after leaving office a very personal memoir-what I call your Black book-in which you reflect on family and your life growing up in the Jim Crow South, the dawn of the Civil Rights era?

RICE: With every implausible event and circumstance in which I found myself, whether it was negotiating with Palestinians and Israelis or getting off a plane that says the United States of America, toward the end of my time in government I just got more and more interested in and compelled by the question that so many people ask me: 'How in the world ...

GaTeS: Did a girl like you ...'

RICE: Right, exactly [laughter]. And I would look sometimes at a particular picture that you saw, Skip, when you came to my house.

GATES: I love that picture.

RicE: This little five-year-old girl with bows and rolled up bangs. How did she become secretary of state? And I was very attracted to trying to tell the story. I always tell people that in order to know how that happened, you had to know John and Angelina Rice. And I wanted to tell their story, both because it explained my story and because it explains a story, I think, of people that are sometimes a little bit forgotten. There was a striving middle class in the segregated South that was somehow in these bizarre circumstances of Jim Crow, yet still getting educated and educating their children and becoming professionals and doing all of the things that then really set us up to be ready when the Civil Rights Act passed. And I wanted to do it not from the perspective of the great leaders of the movement or certainly not as an historian or as a sociologist. My great friend Clay Carson, an historian at Stanford, gave me very good advice. I talked to him before I wrote the book. And I said, 'You know, Clay, I'm not really an historian of this era.' And he said, 'That's not what you're going to do here. This is how you remember it as a little girl.' And it freed me then to take the perspective of telling the story of these forgotten people as a little girl. I think theirs is a generation to which we owe a lot.

Gates: And if we don't remember them, they will be forgotten.

RICE: They'll be forgotten because of the way that historians, for a lot of very good reasons, often focus on the leaders and the rulers of a particular period. And you know very little about the normal people, the average people, the ordinary people. And yet, these ordinary people-and my parents were ordinary peoplewere living in extraordinary circumstances and were getting extraordinary results.

GATES: That is why I like doing people's family trees. Because I am discovering and reuniting you with lost ancestors. And they are all extraordinary. Just finding them makes it extraordinary. But you've written a beautiful book.

RicE: Thank you.

GATES: We've been talking about leadership-how it is nurtured and how it is exercised. One of the greatest challenges our nation's leadership has faced-or some would say created - in the past decade is our current state of war, first in Afghanistan, then in both Afghanistan and Iraq, and now again in Afghanistan. You have said that you don't regret and would not reconsider the decision to invade Iraq.

RICE: Right.

GATES: So let's take that for granted. But didn't we leave Afghanistan too soon? Did the Bush administration erroneously declare victory and open another major military front before some critical strategic objectives had been accomplished? What do you think in retrospect?

RicE: Well, we knew that Afghanistan was not finished when we decided to deal with Saddam Hussein. We were dealing with a Saddam Hussein who had been there as a threat since 1991 and the end of the first Gulf War. And it's a question of when 
do you finally deal with that threat? We believed that the United States was more than capable of continuing the battle in Afghanistan. We had in fact had a lot of successes in getting Al Qaeda out of the country, routing the Taliban. And until 2005, 2006, when some things went wrong in Pakistan, Afghanistan was going in a reasonably better course. But even so, I don't think this was an issue of either the attention of leaders, because I remember spending a lot of time on Afghanistan as well between 2004 and 2007, or resources. Sometimes the United States has to do two things at once.

Gates: So who lost Afghanistan?

RICE: Oh Afghanistan isn't lost. Afghanistan can be won in the sense that it can be stabilized to the point that the Taliban is not an existential threat to the Afghan government. It's not going to be a Jeffersonian democracy. And it's not going to be even probably as advanced as Iraq will be, because Iraq, for all of its troubles, is a much wealthier society, a much more highly-educated society.

GATES: With more infrastructure.

RICE: Yes. Afghanistan is a place that was in civil war for almost thirty years before we had the events of 2001. And when you fly over the high mountains of Afghanistan, you realize that basically they were bequeathed high mountains and dirt, and it's a very poor place, the fifth poorest country in the world. Very tribal, without a very strong central leadership. So it was always going to be hard. But, through building Afghan security forces and giving them a chance at decent government, you can get to the place that the Taliban can't overthrow the Afghan government and then it'll be a long evolution until it looks fully stable.

GATES: So the Afghan government can get there in this time period?

RICE: I think that in the time period that was recently set out at NATO, 2014, one could imagine getting to the place that the Taliban is no longer an existential threat. It's not going to be easy. And it will take a lot of focus on building Afghan security forces. One of the problems you have in Afghanistan is just the low level of literacy. I remember when I was reading some of the interviews as they were demobilizing people out of the militias in 2001 and 2002. They were some of the saddest interviews I think I ever read. You would see a twenty-five year-old man and they would say 'Can you read?' 'No.' 'Do you have any skills?' 'No.' 'How long have you been fighting?' 'Since I was ten.' That's the problem in Afghanistan.

GATES: Let me ask you the hardest question that ordinary Americans grapple with concerning the war: Why should an American give their child to be sacrificed?

RicE: Well, we left Afghanistan once before. After we helped defeat the Soviet Union in 1989 in Afghanistan, we left and we stopped being interested in Afghanistan. And the extremists came across the border from Pakistan. You know, Taliban means student. And these were in a group of extremist students, Pashtun students, who lived on the border between Pakistan and Afghanistan. They made league with a cleric named Mullah Omar and they took over the country, which was in ruins. They put in place the most barbaric regime really, even compared to regimes like North Korea. People may remember when they blew up the historic Buddhas. They were also killing women, executing them in a soccer stadium that had been given by the UN development agency. And they suggested that a new soccer stadium should be built so they could play games in one and continue killing women in the other. These were crazy people. But these crazy people allowed Al-Qaeda to burrow in there. They allowed Osama bin Laden to relocate there from Sudan. They allowed Al-Qaeda then to have the benefit of territory in which to train and equip and finance themselves, leading directly to September $11^{\text {th }}$. That's why we have to care about failing states. 
Gates: People from other countries, especially European allies, have often regarded Americans as clumsy, lacking in cosmopolitanism, arrogant, even selfcentered. But they have usually expected to end up on the right side of history in any great cause. There is a sense in many quarters that the unilateral decision to invade Iraq might have changed that and might have changed the international perception of the United States. That the United States went from an image of sometimes difficult or awkward Big Brother to a truly frightening and unpredictable and potentially irrational actor on the world stage. How would you react to that?

RicE: Well, first of all, the United States from time to time has always been viewed that way. Remember the period of Ronald Reagan? The Evil Empire was going to end up on the ash heap of history? And I remember thinking myself at the time, and as a Soviet specialist, 'Boy, that's really undiplomatic,' you know? But he was right. And of course a lot of the policies that he undertook, which were very unpopular, protested by a million people in the streets in Europe, ended up helping to condition the circumstances in which the Soviet Union collapsed and the Cold War ended peacefully.

GATES: They helped to bankrupt them.

RICE: They helped to really crack their will to continue to confront the United States. So the United States is never, frankly, going to be loved. The question is, is it respected? And its values, its reputation for being a place where you can come from humble circumstances and do great things, that's universally admired in the world. The decision to invade Iraq was not popular, but there were a lot of countries that were a part of the coalition. Not just Great Britain and Australia and Poland, but a number of smaller countries throughout Eastern Europe. And not too long after the war was over, the UN stepped in with a very fine special advisor who helped to organize the elections and so forth, and the world came back together around Iraq. So while many may have felt that the U.S. didn't wait long enough, our question was how many security council resolutions over how many years does he have to violate before somebody does something about it? And at some point the United States took a decision.

It's also the case that, by the way, there haven't been very many UN resolutions authorizing the use of force, including in the Balkans when the Clinton administration decided to take on Milosevic. They could not get a UN Security Council resolution because of Russian objection. So it's more often the case that there is not a UN resolution authorizing force than that there is a UN resolution authorizing force. And one other thing, the image of Americans as kind of clumsy and we don't speak anybody else's languages and we are not very good at geography. . . . I'm constantly on a mission to get Americans to speak other languages and to know the world. But I often said to my European colleagues there are two things about Americans you can always count on. First of all they're optimistic and idealistic enough to believe that the world doesn't have to be like it is, that it can be better.

GATES: That's true.

RICE: And secondly, they may not know where a lot of places are, but when it comes time to fight for somebody else's freedom, they've been there. So they may not have heard of Normandy before the Normandy invasion, but you better be awful thankful that they were willing to fight for your freedom. And as a result, the French were allowed to continue to speak French.

Gates: Absolutely. That's a good way to put it. Our image in the Muslim world is not good now, by all accounts. Can this be attributed solely to the war, or are there other factors involved? 
RICE: Well, our image vis-à-vis Muslims is a complicated issue because on the one hand, Saddam Hussein killed more Muslims than the United States and the rest of the world combined one thousand times over. This is somebody who killed a million people in the Iraq-Iran war, who put 400,000 people in mass graves. His own people. He used chemical weapons both against Iranians and against his own people. So the question became 'Was getting rid of Saddam Hussein a good thing for the Muslim world, given his record?' The United States intervened in Kuwait on behalf of Muslims, in Bosnia-Herzegovina and in the Balkans on behalf of Muslims, under the Clinton administration and the Bush administration. And so these wars were actually not fought against Muslims, they were fought on behalf of innocent Muslims who were being murdered by authoritarian dictators, who were themselves Muslim.

I think there is a lot of propaganda out there about the United States. I think there is a lot of insincerity by some leaders in the Muslim world who are terribly fearful of their own people, because heaven forbid that they would ever give their street the right to vote. ${ }^{1}$ So I think there's some insincerity and hypocrisy there. I used to say to some of my Arab colleagues and friends when they would rail about the Palestinian issue, 'But isn't it true that you've expelled Palestinians from your own country?' Some of the most entrepreneurial, tolerant, wonderful people in the world are the Palestinians. And they've been mistreated in the Arab world almost universally. So there's some hypocrisy there. And then I thought that the Arab development report that was done by the UN a few years ago pointed to something else very fundamental; the question of why the Arab world continues to fall behind in the sciences. The number of patents done in South Korea on any given day is one hundred-fold more than those done in the entire Arab world. Why is that? And younger, more progressive Arab leaders are starting to ask the same questions. And they're starting to recognize the importance of education for both men and women. Even in a conservative society like Saudi Arabia, where King Abdullah has built a magnificent university with a $\$ 10$ billion endowment, women are going to be educated in separate classrooms, but they're going to be educated. And educated in science and technology. So maybe the Arab world, the Muslim world, is starting to turn and look inside a little bit more for explanations for what has happened to it.

GaTES: I could not allow the opportunity to interview the former Secretary of State go by without talking about these pressing international issues. But I want to return to where we started the interview: leadership and Black America. Was President George W. Bush misunderstood by Black America? And if so, who bears the greatest responsibility for this misunderstanding? Black leadership or the Bush administration?

RICE: President Bush was fundamentally misunderstood by Black America. And I'll come to the question of responsibility. On the one hand, he's a Republican and I have said very often that part of the problem is the Republican party has a lot to live down for what happened in 1964 when the Civil Rights Act was passed and when some tried to take advantage of that to build a southern strategy to build a base for the party among disaffected segregationists.

GaTES: Which they did quite effectively.

RICE: But at a great cost to our soul in the Republican party, which should have been, as most Republican Senators were, most Republican Congressmen were, foursquare behind the Civil Rights Act. A young Congressman from Illinois, Donald Rumsfeld, for instance, supported the Civil Rights Act. So there's that history. And a pity that the party of Lincoln would do that. Secondly, for a long time I think that the party didn't speak in a language about issues that are American issues but perhaps have a more fundamental effect on the Black community; for instance, the nature of 
the public school education system. President Bush tried to speak to those issues. One of my first conversations with him was not about foreign policy. In 1998 we were at Kennebunkport together thinking about what he might do if he ran for president. And he talked about the soft bigotry of low expectations and how people didn't expect enough of Black kids. He talked about the minority achievement gap and how could it be that we had so many Black and Hispanic kids who couldn't read at third grade level six or seven years into their education? He had a desire to do something about that. And even though he didn't want to use quotas in the University of Texas system, he had gone to a top ten percent strategy so that if you were in the top ten percent, which brought many, many more Blacks into the number, you got into the UT system. So he was attuned to these issues from the very beginning. Yes, he cared about minorities and their forward progress.

So whose responsibility was it? Well, I don't know that Black America and a lot of traditional media outlets were willing to listen to that story. But after September $11^{\text {th }}$, we had no choice. President Bush had no choice but to become a war president. He didn't go to Washington to be a war president. He wanted to redefine in many ways what it meant to be a Republican. When he said compassionate conservatism, he meant caring about education of all children, particularly minority children, and that's why No Child Left Behind was so important to him. He wanted to reform immigration policy. He wanted to think about how we could deal with entitlements in a way that didn't disadvantage the poor, but made them affordable. And September $11^{\text {th }}$ and a war presidency drowned a lot of that out.

GATES: So then whose fault? Is there anything that could have been done?

RICE: I think it's mostly circumstances, but it's possible that everybody including the White House could have been more attuned to how those messages were being heard. There wasn't enough effort to go and speak to people. I remember shortly during and after Katrina was unfolding, I talked to the president and said, 'Mr. President, we have a race problem.' And we reached out to Bruce Gordon, who was president of the NAACP at the time. You know, the White House can be sometimes an isolated place and you have to be constantly sure to be reaching out beyond the boundaries of the people who would normally be a part of your constituency and pull them in. The thing President Bush was really proud of was that he had taken twenty-eight percent of the Black vote in Texas. So those who got to know him best believed in this man as someone who cared about all Americans and I'm sorry it didn't get better communicated.

GATES: I heard him on Leno a couple of weeks ago. And he said the worst moment in his presidency was Kanye West effectively calling him a racist, saying he didn't care about Black people. Help us to understand that. Was that true?

RICE: It was true. I remember he was so hurt-it was a shock to him that anybody would think that he would somehow let people suffer because they were Black. There was nothing worse you could say about him or about the president of the United States than that. And that says something, too, about how he viewed himself.

GATES: It does. I was shocked. I was laying in bed watching and was thinking 'Wow, this may be worse than 9/11.'

RICE: Maybe over time this will get straightened out. But Bush was really, really saddened and angered by it.

Gates: So did you and Colin Powell make Barack Obama president? Did you prepare the way? Were you the John the Baptist for the Jesus?

RICE: [laughter] Oh, I see. Well, I don't know about that analogy. But I do think that slowly but surely Americans saw Black Americans, African Americans, in positions that they would never have dreamed of ten years before ... 
GATES: In a million years.

RICE: First, the highest ranking military officer is Black. OK. Now the chief diplomat and the national security advisor at the same time are Black. And then you have another Black secretary of state and OK, well maybe this is all right. And then now you have a Black president. Yes, I think there has been a progression that's been hopeful.

GATES: I think that's absolutely the case. If America is an idea, as you have said numerous times - the idea of a land of freedom and opportunity for all—can you talk a little bit about how we as a country have navigated different parties' conceptions of that idea? We seem to be getting more and more polarized, particularly since President Obama was elected. So it's not always clear to me that that idea means the same thing to all sides in our country anymore. And that's different than when we were growing up.

RICE: I think the American idea still has powerful resonance with almost all Americans. And that idea is that we are a free people who are protected both by and from our government and we are a free people who can have the opportunity to fully express ourselves and fully reach our potential through life, liberty, and the pursuit of happiness. And that is our birthright as Americans. I think most Americans still believe that that is the American idea. Where we're breaking down is in the confidence that it is really true. And we had great confidence-even in segregated Alabama, where you could not go into a restaurant-that the American idea was still for us. Because all we had to do was to get the United States to be what it said it was. We didn't have to make the United States be something different. It just had to be what it said it was. And now, if you are in east Oakland or south-central LA or the poorest parts of Boston, do you really still believe that? When I can look at your zip code and I can tell whether or not you're going to get a good education, is the American idea really alive and well? And that, I think, is what is causing the tension and the friction.

By the way, it's not just poor Americans. Families that always believed that their kids would be better off than they were are now not so sure. And the house that was the great pride of every American family, is now worth half its value. And I think our anxiety and our anger and our desire to want to shake Washington and say 'Listen to me' is driven not by the unraveling of the idea, but the unraveling of the belief that the idea is more than just a myth. It's real. And that's a great danger to us as a country because we are not held together by blood or religion or nationality. We are African Americans and Mexican Americans and Indian Americans and Korean Americans and German Americans and we are Muslims, Jews, Protestants, and Catholics and we're nothing at all, some of us. So if we are not held together by religion or by blood, we are only held together by that idea. And if that idea isn't true, then we will come apart as a society and as a country.

Gates: You are talking about economic scarcity and the class divide in this country. Is it going to get better? Or unfortunately worse?

RICE: We have lost time and we've lost ground to deal with the implications of globalization. The implication of globalization is that the $\$ 18$-an-hour unskilled job is gone forever. That job, by the way, isn't even in China anymore. It's gone someplace else even for the Chinese. And our skills and our education as a people don't match up well with the jobs that are available. Now ask anybody on Route 128 or in the Silicon Valley, 'Can you find enough engineers?' They will tell you no. Go to some places and ask if they can find enough people who can write well, forget math and science. And they'll tell you no. So somehow we have this divorce between the education and training of our people and the jobs that are available. And the impact 
of globalization is getting faster and wider and our ability to match up with it is diminishing and we are losing time. So that, I think, is the real economic challenge.

Gates: Can we get our mojo back? I'm talking about all Americans now. Do we have leaders who can energize us? Do we have a community that will work to carry out our leaders' vision?

Rice: Oh, sure. We have to do some really hard things, you know. We've got to get our education policies right immediately. We've got to do something about immigration. Immigrants are not the enemy. Immigrants are the life's blood of the United States. We have to get the economy going again. You know, the private sector has to lead that growth. But I'm a real optimist about America because so many times we have made the impossible seem inevitable. And we are not a people that are given over to wringing our hands. I am an optimist about our ability to deal with the current challenges.

GATES: Thank you, Dr. Rice, for a marvelous interview.

Rice: Thank you.

To view the video version of this interview, visit The Vine: African-American Power Players Talk Leadership at http://www.theroot.com/multimedia/vineblack-power-players-talk-leadership

Corresponding author: Professor Henry Louis Gates, Jr., W. E. B. Du Bois Institute for African and African American Research, 104 Mount Auburn Street, 3R, Cambridge, MA 02138. E-mail: gates@ harvard.edu

\section{NOTE}

1. See remarks of Secretary of State Condoleezza Rice at the American University of Cairo, Monday, June 20, 2005. 